\title{
Statistics and the Ontario Lottery Retailer Scandal
}

\author{
Jeffrey S. Rosenthal, Department of Statistics, University of Toronto \\ (Version with detailed references: August, 2013; slightly revised October 2013.)
}

\section{Introduction}

This paper describes the role that simple statistical analysis played in exposing the Ontario lottery retailer scandal, which ended up becoming major front-page news in Canada and leading to numerous consequences including legislative debate, the firing of two CEOs, several criminal charges, jail time, and payouts totalling over twenty million dollars. The story stands as a forceful testament to the importance and power of statistics.

\section{How It All Started}

I am primarily a theoretical statistics researcher [1], but after publishing a successful general-interest book about probabilities [2, 3], I did a lot of public speaking and media interviews, especially in Canada [4]. I was interviewed about such things as crime statistics [5, 6], pedestrian death counts [7, 8], decision making [9], game show strategies [10], hockey forecasts [11], lottery jackpot probabilities [12, 13], calculating risk [14], contests [15], election polls [16], and more.

Because of this, I was approached in the summer of 2006 by Harvey Cashore and Linda Guerriero, producers for the investigative journalism television program The Fifth Estate on the CBC (i.e., the Canadian Broadcasting Corporation: Canada's national broadcaster, modelled after the BBC in the U.K.). They requested my help with a news story involving lottery fraud. I actually initially declined their request, since I was busy with other projects and was just leaving for a research trip to Europe, so I didn't particularly feel like doing yet another brief television interview. However, the $\mathrm{CBC}$ was unable to find an appropriate replacement, so they contacted me again upon my return, and I agreed to meet with them. Then, the more I heard about the case, the more interesting it sounded.

I was told the story of Bob Edmonds, a mild-mannered elderly gentleman from the small town of Coboconk, Ontario, Canada. He always played the same lottery numbers, but (like many players) he left it to the store clerk to check if he had won anything. On July 27, 2001, he brought two tickets to his local convenience store. One of these tickets won him 
a free ticket, which the clerk gave him. But the other ticket won him $\$ 250,000$, a fact which the clerk kept to herself. The clerk later tried to claim the winning ticket as her own. Although the lottery company was suspicious, the clerk finally managed (after a few maneuvers, including a sneaky meeting with Mr. Edmonds in which she convinced him to share his old tickets and reveal his lottery purchase patterns) to convince them to pay her the $\$ 250,000$.

When Mr. Edmonds heard about the clerk's win, he realised what had happened. He then spent the next 3.5 years struggling to convince the Ontario Lottery and Gaming Corporation (OLG), the Ontario Provincial Police, and ultimately a court judge of the merits of his case. He finally prevailed in March 2005, when the OLG agreed to pay him $\$ 200,000$ of his winnings, but only on the condition that he promise to keep his case confidential [17].

Mr. Edmonds' case is a tribute to one man's brave persistence in fighting for justice. The CBC then wondered if the OLG's insistence on confidentiality was motivated by concern about other possible similar cases. They asked me to examine some related data from a statistical point of view.

\section{Facts and Figures}

So what did the numbers say?

The CBC ascertained (through a Freedom of Information request) that in the period 1999-2006, there were a total of 5,713 major (i.e., $\$ 50,000$ or more) lottery wins in the province of Ontario. (This figure combines together all of the lotteries sold in Ontario, such as the biweekly Canada-wide "Lotto 6/49" which involves choosing 6 distinct numbers from

1 to 49 thus giving probability $1 /\left(\begin{array}{c}49 \\ 6\end{array}\right)=1 / 13,983,816$ of winning the jackpot.) Of these 5,713 major wins, about 200 (3.5\%) were recorded as being won by lottery retailers, i.e. by people who worked in stores that sold lottery tickets. (The OLG records were rather spotty, so even these basic facts had to be carefully assembled. Furthermore, retailer wins were only recorded if the lottery winner answered "yes" when the OLG asked if they worked at a store, so the true figure was probably even higher than 200.)

The question then became, is 200 wins too many? How many of the 5,713 major prizes should we have expected these sellers to win? And, what are the odds that they would win 200 or more of them honestly, i.e. by pure luck alone?

To answer these questions, we first needed to know the total number of retail lottery sellers in Ontario. The OLG said they didn't know this figure, so we had to investigate on 
our own. We knew there were 10,300 lottery ticket sales locations in Ontario. Furthermore, a Fifth Estate survey of 200 locations gave a sample average of 3.2 employees per location, with a sample standard deviation of 1.65. This gave a $95 \%$ upper limit of about $3.2+$ $1.97 \times 1.65 / \sqrt{200}=3.43$ employees per location on average, i.e. less than 3.5 , working out to $3.5 \times 10,300=36,050$ sellers in total. We later learned that an OLG executive had testified in an unrelated court case that there were "50,000 or 60,000" such sellers, suggesting a new upper limit of 60,000 sellers. Adding to the confusion, just five days before the Fifth Estate program was to air, the OLG unexpectedly presented the CBC with a brand new table [18], now claiming a total of 140,000 sellers - which turned out, on closer inspection, to mean 101,000 active sellers plus 39,000 annual "turnover" (i.e., former employees, who weren't actually relevant since the issue was whether they were retailers at the time they won their prize). So, this suggested a new upper limit of 101,000 sellers (though this figure was probably inflated, e.g. it included huge numbers of Grocery and Pharmacy workers even though most of them don't actually handle lottery tickets). In our calculations, we considered all of these possible values.

We also needed to know how much these sellers spend on lottery tickets. Again the OLG said they didn't know. So, the Fifth Estate survey asked about this too. Of the 195 employees who responded, 131 said they played the lottery, and their self-identified amounts spent per year on lottery tickets had a sample mean of $\$ 476$, and sample standard deviation of $\$ 602.50$ (giving a mean standard error of $\$ 602.50 / \sqrt{131}=\$ 52.64$ ). Putting these facts together led to an upper limit on average retailer annual lottery spending which was approximately 1.5 times as much as the average annual lottery spending of all Ontario adults (including those who never play). (The OLG later conducted their own survey [19] and got a fairly similar answer, 1.9. And Corporate Research Associates Inc. later studied [20] this same question in Atlantic Canada and obtained a factor of 1.52, virtually identical to the Fifth Estate figure.)

\section{Putting it All Together}

From all of these numbers, what could we conclude?

The first question was, how many of those 5,713 major lottery wins from 1999-2006 would we "expect" retailers to win, in the absence of any fraud or cheating? As a simple approximation, I figured that the fraction of lottery prizes that we would expect retailers to win should be equal to the fraction of all Ontario lottery tickets that they buy, or (even simpler) the fraction of lottery ticket sales dollars that were spent by retailers. (This approach ignored such subtleties as precisely which types of lottery games were played by which people, 
but there was no indication that retailers played different types of games than anyone else, so I didn't worry about that issue.)

Of course, the answer to this question depended on which of the above employee counts we used, so we considered them all for completeness. If we used the upper limit of 60,000 sellers (from the OLG's court testimony), together with the spending factor of 1.5 (from the Fifth Estate survey), then since there were a total of about 8,900,000 adults in Ontario during the time period under review, it followed that we would expect lottery sellers to win approximately

$$
5,713 \times \frac{60,000 \times 1.5}{8,900,000} \doteq 57
$$

i.e. about 57 , of those 5,713 major prizes.

This figure of 57 is, indeed, far less than the 200 major prizes that the retailers actually won. So, did that indicate cheating? Or, could the retailers have won so many prizes simply by chance? After all, lotteries are inherently random, and anyone can get lucky and win. To consider this question, I needed a probability distribution for the number of the prizes that retailers would win in the absence of fraud or cheating.

I figured that since the number of retailer wins is the result of lots of different tickets, each having a very small probability of winning, this probability distribution should be well approximated by the famous Poisson distribution. So, the probability of the retailers winning 200 or more prizes by luck alone should be approximately equal to the probability that a Poisson distribution with mean 57 will give a value of 200 or more. This probability is easily computed (e.g. using R), and turns out to be unimaginably small: less than one chance in a trillion, trillion, trillion, trillion. (Of course, this probability assumes that the figure of 57 is correct, i.e. that the imputed facts about retailer counts and spending patterns are correct - a subtlety which was sometimes forgotten in the ensuing reportage.)

Even taking the largest OLG estimates, i.e. 101,000 sellers spending an average of 1.9 times as much as the general adult population, we would still expect just 123 major wins by sellers over this time period. The probability of their winning 200 or more major prizes would then be less than one chance in seven billion - again absolutely inconceivable.

We also considered retail store owners (as opposed to other employees) as a separate group. Those owners won about 83 of the major wins between 1999 and 2006. We didn't know the precise number of retail store owners (and the OLG wouldn't say), but even under the most generous assumptions, we would expect at most 26 owner wins - far fewer than 83, which would again be extremely unlikely (less than one chance in a trillion trillion). This 
provided still more evidence of fraud, specifically regarding store owners.

It was also possible to break down the retailer winners according to what type of store they worked at. Indeed, retailers working at independent convenience stores represented only about one-fifth of all the lottery retailers, but won a much higher fraction of the retailer major prize wins. The OLG wouldn't tell the CBC precisely how many, but an OLG "FAQ" web page [21] later admitted that 101 out of 190 identified insider wins, or 53\%, were specifically from sellers at convenience stores. Once again, it was inconceivable that such a large number of wins could have arisen purely by chance, thus providing further evidence of fraud specifically at convenience stores.

So, no matter how you sliced it, it was clear that lottery sellers were winning significantly more major lottery prizes than could be accounted for by chance alone. The statistics had proved the existence of widespread lottery fraud. With that, I presented my detailed analysis [22] to the CBC, congratulated myself on a simple consulting job well done, and moved on to other matters.

\section{Making a Splash}

The Fifth Estate episode [23] finally aired on the evening October 25, 2006. That morning, even before air time, I woke up to see that this episode (shared in advance with other media by the $\mathrm{CBC}$ ) had already become a huge news story. My statistical analysis was described on the front page of a national newspaper [24] under the headline "Lottery insiders win big bucks: Odds of Ontario results are astronomical, investigation by CBC program reports".

The story's statistical conclusions were a lead item on most Canadian television news broadcasts and newspapers that day and beyond, with headlines like "Lottery-winning retailers beating statistical odds" and "Those big winnings may have been yours" [25, 26, 27, 28, 29, 30, 31, 32, 33, 34, 35. They were discussed in newspaper editorials with titles like "Another lottery gamble" and "Keep an eye on your winnings" [36, 37, 38]. They were even picked up internationally, by e.g. Reuters [39] and a Freakonomics blog entry [40] and a Spanish blog [41]. Hundreds of lottery customers posted in online forums to express outrage at having been potentially defrauded in this way, and I was flooded with media interview requests. For a few days, it seemed that virtually everyone in Canada was discussing lottery retailer fraud and the statistical evidence involved.

Needless to say, this was the first time that my statistical work became front-page news! 
The issue was also debated in the legislature of the Ontario provincial government (which oversees the OLG). The government was peppered that day and the next with questions [42, 43, 44, 45] such as:

Mr. Robert W. Runciman (Leeds-Grenville): My question is for the Minister of Public Infrastructure Renewal. Minister, today there are disturbing reports that over the last several years more than 200 lottery insiders have won prizes in excess of $\$ 50,000$. Jeffrey Rosenthal, a U of T professor, says that it's "extremely unlikely" these insiders would hit the jackpot that many times. The story, which is going to air on The Fifth Estate tonight, suggests that two thirds of these insider wins may have involved deception. Minister, can you tell us when you became aware of this issue and whether or not you plan to investigate the matter to ensure that Ontarians are not being defrauded of their rightful winnings?

and

Mr. Peter Kormos (Niagara Centre): A question to the Minister of Public Infrastructure Renewal: I too want to ask you about those over 200 incredibly lucky Ontario lottery retailers who have won prizes worth more than $\$ 50,000$ each in the last seven years. The statistics indicate that they beat odds of a trillion trillion trillion trillion to one. That's odds of one quindecillion to one. Why wouldn't that phenomenon in and of itself have rung alarm bells in the OLG, rather than waiting for the CBC to blow the whistle?

Needless to say, this was the first time that my statistical work was a topic of legislative debate!

\section{Responses and Consequences}

At first, the OLG tried to refute the statistical findings. They denied there was significant lottery fraud [46], called the statistical analysis "simplistic" [27], insisted that the Edmonds case was an "isolated" one [24], and hired their own statistical consultants in an attempt to discredit me [21]. The OLG CEO, Duncan Brown, even stated on television that "What was missing from the Fifth Estate's numbers was the frequency of play of the retailers" [46], which was not only insulting but also completely false (as was clear from my report, which was available on the CBC website). This was the first time that my statistical work was opposed so vigorously and publicly, which made me feel rather uncomfortable (and also gave me a grudging sympathy for politicians, who are publicly criticised so frequently). However, the OLG tactic had very limited success, due to the sustained customer outrage.

The Ontario Ombudsman, in charge of investigating issues of concern which fall under the purview of the Ontario government, stepped in to investigate [47]. A few months later he 
issued his report [48, a scathing indictment of the OLG's "buddy buddy" relationship with the retailers which caused it to turn a "blind eye" to questionable winnings [49, 50] because

it was "fixated on profits rather than customer service" [51]. The report concluded that "Without question, insiders have won big over the years ... millions of dollars have been paid out in what are dishonest claims." The report in turn put additional pressure on the Ontario government, including calls for the relevant minister to resign [52]. The government resisted such calls [53], but instead fired the OLG CEO [54, 55]. (Then again, the CEO had misleadingly insulted my statistical analysis, so I didn’t mourn him for long.)

Needless to say, this was the first time my statistical work led to anyone getting fired!

On the positive side, the scandal caused the OLG to institute various policy reforms [56, 57, 58]. The stores' ticket checking machines must now be viewable by customers, and make loud noises to indicate wins. Customers are now required to sign their name on their lottery tickets before redeeming them, to prevent switches. New self-checker machines have been installed to allow customers to easily learn what they've won before handing their tickets to anyone else. And ticket sellers cannot purchase lottery tickets at their own store. All of these measures are designed to ensure that future customers cannot be cheated in the manner that Edmonds - and probably many others - were.

In addition, a forensic audit was conducted which concluded that, as we suspected, retailers had actually won far more lottery prizes than was originally recorded [59, 60]. Also, the negative publicity prodded the OLG to pay Mr. Edmonds the remainder of his winnings, and write him a formal letter of apology - just days before he died of cancer on April 2, 2007 [61, 62, 63]. My own involvement continued, with such activities as speaking at a Toronto Police Fraud Squad conference [64] and being asked to write an article about lottery fraud for the Royal Canadian Mounted Police newsletter [65]. Overall, the investigation had led to policy reforms and to exposing a number of important truths. I was pleased with the role that statistics had played in bringing this about - and thought that would be the end of the story.

\section{Moving Beyond Ontario}

Repercussions of the story soon moved beyond Ontario. National press coverage caused customer outrage in British Columbia (B.C.) as well. Initial assurances that the lotteries in B.C. were "safe" [66] were rightly questioned [67], and the ombudsman in that province launched his own investigation [68]. Some months later he concluded [69] that there were 
excessive retailer lottery wins there as well, and that their lottery system was "open to fraud by retailers trying to cheat customers". The B.C. government followed Ontario's lead by firing the president of the B.C. Lottery Corporation [70] - thus bringing to two the number of CEOs felled by this statistical story. Under increased scrutiny, the number of retailer wins in B.C. later dropped [71].

The province of Nova Scotia provided another interesting case. When the Ontario story first broke, the Atlantic Lottery Corporation (ALC) defiantly declared that their system was "foolproof", saying that "At Atlantic Lottery our retailers, our staff, none of the people involved in the sale of our products, has the potential to impact the outcome of any of our products." [72] This surprised me since I saw no reason that the situation in Atlantic Canada would be fundamentally different from Ontario. And I wasn't the only one. The Nova Scotia Gaming Corporation (NSGC), which had the role of overseeing the Atlantic Lottery Corporation within the province of Nova Scotia, hired me to get to the bottom of the situation there. I performed a similar analysis [73] to what I had done in Ontario, concluding that Nova Scotia retail store owners had won 22 of 448 major $(\$ 25,000+)$ lottery prizes during the period 2001-2006 (excluding 7 which were already under investigation). By contrast, they would be expected to win just over one such prize. It was, again, inconceivable that these wins could have been by luck alone. So, once again, this provided convincing evidence of retailer fraud. (And, 18 of the 22 wins were by independent convenience store owners, indicating once again that most of the problem was in that sector.) These and related findings were reported and led to lottery policy reforms and further enquiries in Nova Scotia as well [74, 75, 76, 77, 78]. It was also discovered that in 2005 the ALC had "hid" a retailer win to avoid suspicion [79]. As a further consequence, the ALC withheld executive bonuses in 2007, and held up their CEO's new long-term contract 80].

Related developments occurred with the Western Canada Lottery Corporation, which oversees lottery operations in three Canadian provinces and three territories. They issued an auditor's report [81] which cautiously re-assured that "no evidence was found of a consumer complaint against a retailer location that corresponded to a prize or validation issue consistent with an identified or potential retailer employee major prize win". The CBC's Western Canada news bureau asked me to investigate this. I performed a brief analysis [82] which concluded that, yet again, the number of retailer wins was too high: retailers won 67 major $(\$ 10,000+)$ prizes in 2003-2006, while their expected number of wins was at most 34, and the probability of this occurring by chance was extremely small. My analysis also broke down the results by province, and found that the individual provincial retailer win 
counts were also too high. My conclusions were reported by the CBC [83], and caused the government and ombudsman in Manitoba to launch a review [84, 85], while attempting to reassure their customers [86].

Perhaps most interesting in the Western Canada case was my discovery [87] of a fundamental error in the previous auditor's report [81. They had computed the expected number of retailer wins by multiplying the retailer count by the "greater play rate" of 1.9 (fair enough), but then dividing that not by the total adult population but rather by the $75 \%$ of the adult population that plays lottery games ([81], page 64). So, they were effectively counting the same $75 \%$ factor twice, which caused them to compute the expected number of retailer wins as $75 \%$ higher than it should have been (but still not as high as the actual number of retailer wins).

In the province of Québec, Lotto-Québec initially tried to assure their customers that they had no fraud problem [88]. However, the lottery scandal story received extensive coverage there as well [89, 90], and led to a detailed television enquiry into possible Québec lottery retailer fraud [91]. This in turn forced Lotto-Québec to bring in additional security measures to protect their customers [92].

Related cases also arose in the United States. An Arizona convenience-store clerk was arrested for claiming a customer's $\$ 1.5$ million jackpot as her own, which a spokesperson for the Arizona Lottery insisted "has not happened before, and I doubt it will happen again." [93] A shop worker in Grand Prairie, Texas, cashed in a customer's $\$ 1$ million winning lottery ticket before fleeing to Nepal [94, 95], and the Texas Lottery Commission refused to pay the rightful owner [96, 97], although this was one of six suspected lottery fraud cases in Texas in 2008-9 [98]. In Iowa, the state ombudsman issued a report criticizing the Iowa Lottery for failing to protect customers from retailer fraud and said it had missed an opportunity to learn from the Ontario lottery scandal [99, 100]. And, in California, the lottery company conducted an elaborate sting operation, reported in detail by NBC News [101. They created fake winning lottery tickets, and had an undercover investigator bring them to be checked in various retail stores. While most retailers reacted honestly, some of them denied that the tickets were winners, and then later tried to claim the prizes themselves - and got arrested and charged with fraud [102]-[110]. The report suggested that the problem also extended to other states. The Minnesota State Lottery then undertook a similar sting operation in 2009 [11], as did the Ohio Lottery in 2010 [112, 113]; both operations resulted in arrests.

It seemed that this was not just an Ontario issue after all. 


\section{Calling the Cops}

The Ontario Ombudsman's report [48] discussed, in addition to the statistical arguments, several specific cases in which lottery winnings had been paid out to retailers despite suspicious circumstances (such as the prize winner not being able to recall their lottery ticket purchase patterns). At first it seemed that these cases would remain as unsolved mysteries: indeed, my statistical analysis could estimate the total number of fraudulent cases, but could not identify specific instances of fraud.

However, the OLG was now taking these cases very seriously. They partnered with the Ontario Provincial Police [114] to investigate in detail. The first case was cracked when four Toronto friends realised that their jointly-purchased lottery ticket from June 2004 had won a $\$ 5.7$ million prize which they had not received. They initially accused each other of theft (thus ruining their friendship), before finally realising that actually the retailer was to blame. After an investigation, convenience store owner Hafiz Malik was arrested and charged with fraud for cashing in their winning ticket in January 2005. Malik confessed and pled guilty in December 2009, and received a one-year prison sentence [115, 116, 117]. The four winners were paid in full plus interest, for a total payout of $\$ 6.5$ million from the OLG [118].

Another case involved a woman who had no idea she was a winner, until the OLG carefully tracked her down. Javed Nazami, the manager of a Burlington convenience store, was charged with fraud and theft for stealing her winning November 2004 lottery ticket and cashing it in himself. The OLG paid the woman the full value of her winnings (this time "only" $\$ 80,000$, or $\$ 94,000$ with four years of accumulated interest) [119, 120, 121].

The most dramatic case involved a \$12.5 million winning ticket from December 2003 which was cashed by the daughter of a convenience store owner two months later. The daughter originally denied that she was related to a retailer, and then couldn't provide details about where she purchased the ticket. The OLG waited for nearly a year before secretly

paying the prize. This case was flagged as suspicious in the Ombudsman's report [48], and was later investigated in detail by the CBC's Fifth Estate [122] - including a secretly-recorded interview with the father who seemed to suggest that if no one can prove fraud, then "finders keepers" prevails.

There was then no further news about this case for 3.5 years. So, I was very surprised in September 2010 when the father and daughter and another sibling were arrested and charged with theft [123]. In this case the OLG had determined that the prize had been paid to the wrong people, but they did not know who the true winners were. In a dramatic 
move, the police and OLG publicly announced that they were "seeking" the rightful winner, and invited applications from potential winners [124, 125]. Unsurprisingly, they received hundreds of claims [126, 127], which they then attempted to sort though and investigate. Finally, in January 2011, a group of seven construction workers who applied late in the process were able to correctly answer all questions about their lottery-buying habits, and they were awarded the $\$ 12.5$ million (or $\$ 14.8$ million with interest) [128, 129, 130, 131].

Needless to say, this was the first time that my statistical work had led to criminal charges, or jail time, or multi-million-dollar payments!

\section{Reflections}

Looking back, I am rather amazed at how the lottery retailer scandal story has unfolded. I never expected this issue to become so big, or to have such wide repercussions: Bob Edmonds was vindicated, customers across the country were outraged, the lottery company was on the defensive, politicians debated, CEOs were fired, criminal charges were laid, people were sent to jail, and over twenty million dollars were paid.

Of course, many different forces were required to move the story along: Bob Edmonds' persistence, the CBC Fifth Estate's fantastic investigative journalism, the Ombudsman's detailed report, extensive police scrutiny, the OLG's later cooperation and analysis, and more. But statistical analysis also played a major role in broadening the issue from one specific case into a widespread concern. This was nicely summarised in a later Toronto Sun newspaper article [132], which began:

For a guy who's never bought a lottery ticket at a corner store, Jeff Rosenthal has sure hit it big. And lottery corporations across Canada would likely wish he would just stop playing their numbers so well. Since 2006, the Toronto math professor has been the brain behind uncovering a suspected massive theft of lottery winnings by sticky fingered store clerks. The ripple effects of his seemingly innocuous number crunching - figuring, on behalf of the $\mathrm{CBC}$, the likely odds of so many retailers routinely becoming winners - has led to the greatest scandal in the history of Canadian lotteries.

I couldn't have put it any better myself.

Acknowledgements: I thank Harvey Cashore, Linda Guerriero, Maggie McGee, and Timothy Sawa for facilitating my involvement in this story, Mike Newton and Radu Craiu for encouraging me to write this article, and Margaret Fulford for extensive assistance with the references (available in full text from hyperlinks below or at probability.ca/lotteryscandal). 


\section{References}

[1] Jeffrey S. Rosenthal. "Research Contributions." [web]

[2] Jeffrey S. Rosenthal, Struck by Lightning: The Curious World of Probabilities. Toronto: HarperCollins, 2005.

[3] Jeffrey S. Rosenthal. "Struck by Lightning: The Curious World of Probabilities." (webpage about the book) [web]

[4] Jeffrey S. Rosenthal. "Author Publicity Activities for Struck by Lightning." [web]

[5] Paola Loriggio. "You're safer than you think: Statistics expert." Toronto Star, January 19, 2008, p. A6. [text] [web]

[6] Dan Gardner. "Why randomness doesn't seem random." The Ottawa Citizen, July 25, 2007. [text]][pdf] [[web]

[7] Metro. "Not so rare for rarities to occur in waves: Professor." Metro (Toronto), January 29, 2010, p. 1. [text]][pdf] [web]

[8] Jennifer Yang. "Numbers don’t always tell the whole story." Toronto Star, January 30, 2010, p. GT4. [text]][[pdf] [web]

[9] Jessica Prois. "Playing the odds with everyday life: Toronto professor to lecture on how to make better choices by considering probabilities." Vegas Seven, February 18, 2010. [text]][pdf]][web]

[10] J. Kelly Nestruck . "The deal breaker: If you're a guest on Howie Mandel's show, you should bring Jeffrey Rosenthal - not your dad." National Post, May 30, 2006, p. B1. $[$ text] $][$ pdf $][$ web]

[11] Mike Strobel. "According to the school of biased observation, it's fated the the Leafs are going to the Cup this year." Toronto Sun, April 13, 2006, p. 6. [text]][email]

[12] Ellen Roseman. "Advice for lottery winners: Chill out." Toronto Star, April 30, 2006, p. A20. [text $][$ pdf $]$

[13] Globe and Mail. "Lotto-fever has Canadians dreaming of striking it rich." Globe and Mail, March 19, 2010. [text] [pdf] [web]

[14] Olivia Ward. "Nervous? There's a way to calculate risk." Toronto Star, October 8, 2005, p. A4. [text]

[15] Surya Bhattacharya. "Statistically speaking, don't leave the house." Toronto Star, March 26, 2006, p. D12. [text]][pdf]

[16] Robert Benzie . "Use caution when approaching polls." Toronto Star, January 21, 2006, p. F4. [text] [pdf]

[17] Canadian Broadcasting Corporation. "Luck of the Draw: Bob Edmonds' Story" (webpage). [pdf] [web]

[18] Ontario Lottery Corporation. "Estimated number of retailer employees selling lottery tickets." October 18, 2006. [pdf]

[19] Research Dimensions. "Re: Retailer Lottery Playing Habits Study \#433.366." October 26, 2006. [pdf] 
[20] Corporate Research Associates. "ALC Retailer Study." November 2006. [pdf]

[21] Ontario Lottery and Gaming Corporation. "Frequently Asked Questions." October 2006. [web]

[22] Jeffrey S. Rosenthal. "Analysis of Insider Ontario Lottery Wins." October 2006. [web]

[23] Canadian Broadcasting Corporation. "Luck of the Draw" (episode of The Fifth Estate), broadcast on CBC Television, October 25, 2006. [web]

[24] Kari, Shannon. "214 lottery 'insiders' won big bucks: Odds of Ontario results astronomical, investigation by CBC program reports." Globe and Mail, October 25, 2006, p. A1. [text] [image] [web]

[25] Canadian Broadcasting Corporation. "Lottery retailers enjoying luck of the draw: Fifth Estate probe." $C B C$ News, October 24, 2006 (webpage). [text]|[pdf]|[web]

[26] Joe Warmington. "Those big winnings may have been yours: How is it that the people who sell lottery tickets do better than those who buy them?" Toronto Sun, October 26, 2006. [text] [pdf] [image] [ [web]

[27] Rob Ferguson and Curtis Rush. "Province to probe the windfalls of lottery retailers: Opposition wants outside investigator; Statisticians lay bets there was fraud." Toronto Star, October 26, 2006. [text][image] [web]

[28] Ian Robertson. "Storekeepers lucky?" Toronto Sun, October 26, 2006. [text][image] [web]

[29] Curtis Rush and Peter Edwards. "Lottery-winning retailers beating statistical odds." Kitchener-Waterloo Record, October 26, 2006, p. A3. [text]

[30] Canadian Broadcasting Corporation. "2006-10-25 (Segment 001" (segment of The National), broadcast on CBC Television, October 25, 2006. Transcript. [text]

[31] Société Radio-Canada. "Méfiance à Loto-Ontario : des détaillants ont volé des billets gagnants à leurs clients. - Avoir en sa possession un billet de loterie gagnant, est-ce un signe assuré que la chance nous a souri? Pas nécessairement" (segment of Le Point), broadcast on SRC Télévision, October 25, 2006. Transcript. [text]

[32] Presse canadienne. "Détaillants de loterie trop chanceux en Ontario?" Le Droit, October 26, 2006, p. 20. [text]

[33] Colin Perkel. "Unscrupulous lotto ticket clerks accused of ripoff: Ontario 'insiders' win millions, TV show says." Calgary Herald, October 26, 2006, p. A6. [text]

[34] Canadian Press. "Lottery-Allegations." Broadcast News, October 26, 2006. [text]

[35] Rob Ferguson. "Dozens report lottery wrongs: Ombudsman 'We've hit jackpot'; Lotto drops fight with victim, 83." Toronto Star, October 28, 2006, p. A3. [text]

[36] Globe and Mail. "Another lottery gamble." Editorial. Globe and Mail, October 26, 2006, p. A20. [text] [pdf] [image] [web]

[37] Guelph Mercury. "Keep an eye on your winnings." Editorial. Guelph Mercury, October 27, 2006, p. A12. [text]

[38] Toronto Star. "Integrity crucial to lottery system." Editorial. Toronto Star, October 31, 2006. [text] 
[39] David Ljunggren. "Update 1-Canada lottery sellers suspiciously lucky - CBC." Reuters News, October 25, 2006. [text]

[40] Stephen J. Dubner. "Yet Another Reason to Not Play the Lottery." Freakonomics (blog), October 29, 2006. [text] [ [pdf] [web]

[41] lvaro Ibez. "Si eres lotero y te toca la lotera...." Microservios (blog), October 30, 2006. $[$ text $][$ pdf $][[$ web]

[42] Robert W. Runciman and David Caplan. "Ontario Lottery and Gaming Corp." In Ontario. Legislative Assembly. Legislative Debates (Hansard). 38th Parliament, 2nd Session (October 25, 2006). [web]

[43] Peter Kormos and David Caplan. "Ontario Lottery and Gaming Corp." In Ontario. Legislative Assembly. Legislative Debates (Hansard). 38th Parliament, 2nd Session (October 25, 2006). [[web]

[44] John Tory, Dalton McGuinty and David Caplan. "Ontario Lottery and Gaming Corp." In Ontario. Legislative Assembly. Legislative Debates (Hansard). 38th Parliament, 2nd Session (October 26, 2006). [web]

[45] Robert W. Runciman, David Caplan, and Jim Watson. "Ontario Lottery and Gaming Corp." In Ontario. Legislative Assembly. Legislative Debates (Hansard). 38th Parliament, 2nd Session (October 26, 2006). [web]

[46] Canadian Broadcasting Corporation. "Luck of the Draw" (episode of The Fifth Estate), broadcast on CBC Television, November 22, 2006. [[web]

[47] Murray Campbell. "Ombudsman to investigate 'insider' lottery wins." Globe and Mail, October 27, 2006, p. A8. [text]

[48] André Marin. A Game of Trust: Investigation into the Ontario Lottery and Gaming Corporation's Protection of the Public from Fraud and Theft. Toronto: Ombudsman Ontario, 2007. [pdf] [[web]

[49] Kerry Gillespie. "OPP told to probe lottery scam $\$ 100 \mathrm{M}$ in prizes won by vendors: Ombudsman blasts the lack of oversight that saw retailers rip off rightful winners." Toronto Star, March 27, 2007, p. A1. [text]

[50] CTV. "Calls for overhaul of Ontario Lottery Corporation." CTV News, broadcast on CTV Television, March 26, 2007. Transcript. [text]

[51] Canadian Broadcasting Corporation. "Lottery agency's close ties to retailers 'fatal flaw': report." $C B C$ News, March 26, 2007 (webpage). [text]|[pdf]|[web]

[52] Kerry Gillespie and Rob Ferguson. "Minister urged to step down over Ontario lottery scandal." Toronto Star, March 28, 2007, p. A8. [text] [pdf] [web]

[53] Karen Howlett. "Lottery minister resists calls to resign." The Globe and Mail, March 28, 2007, p. A9. [text] [pdf] [web]

[54] Canadian Broadcasting Corporation. "Chief of Ontario lottery corporation dismissed." CBC News, March 23, 2007 (webpage). [text] [pdf] [web]

[55] Robert Benzie and Debra Black. "Fired lotto chief 'in shock'." Toronto Star, March 24 2007. [text] [pdf] [web] 
[56] City TV. "Ontario Lottery introduces new rules to protect you from fraud." CityNews Toronto, November 9, 2006. [text]][pdf] [web]

[57] Murray Campbell. "Lottery security tightened after insider jackpots." Globe and Mail, November 10, 2006, p. A10. [text]

[58] Chinta Puxley. More lotto security won't help: ombudsman." Winnipeg Free Press, November 10, 2006. [text]

[59] Canadian Broadcasting Corporation. "Insider lottery wins almost double earlier estimate: analysis." CBC News, February 4, 2009 (webpage). [text] [[pdf] [web]

[60] Allison Jones. "Lottery winnings investigated." Globe and Mail, February 5, 2009, p. A12. [text]

[61] Canadian Broadcasting Corporation. "Man who sparked probe of Ontario lottery agency dies." CBC News, April 2, 2007 (webpage). [[text]|[pdf] [web]

[62] Langan, F.F.. "Bob Edmonds, draftsman, 1924-2007." Globe and Mail, April 4, 2007. [text]

[63] Kitchener-Waterloo Record. "A lottery winner who was a hero." Editorial. KitchenerWaterloo Record, April 4, 2007. [text]

[64] Toronto Police Service. "International Fraud Investigators Conference." Press release. The Toronto News, December 11, 2007 (webpage). [text]][pdf] [web]

[65] Jeffrey S. Rosenthal. "Lottery fraud: Solving crimes using math." RCMP Gazette magazine 70(1) (2008), 18-19. [web]

[66] Chad Skelton. "Lotteries safe to play in B.C. officials say: TV program probes why Ontario retailers win so often." Vancouver Sun, October 26, 2006, p. A2. [text]

[67] Vancouver Sun. "B.C. gamblers deserve ironclad proof that insiders are squeaky clean." Editorial. Vancouver Sun, October 30, 2006. [text]|[pdf]|[web]

[68] Kari Shannon. "B.C. to investigate who wins lotteries." The Globe and Mail, December 19, 2006, p. S3. [text] [pdf] [web]

[69] Canadian Broadcasting Corporation. "B.C. lottery system slammed by ombudsman." CBC News, May 29, 2007 (webpage). [text] [pdf] [web]

[70] Canadian Broadcasting Corporation. . "B.C. lottery boss terminated." $C B C N e w s$, June 1, 2007 (webpage). [text] [ [pdf] [ [web]

[71] Chad Skelton. "B.C. Lotteries says ticket retailers do not win more than the public." Vancouver Sun, August 2, 2008, p. A2. [text]][pdf]|[web]

[72] Canadian Broadcasting Corporation. "Atlantic Lotto confident it's foolproof." $C B C$ News: Nova Scotia, October 26, 2006 (webpage).[text]|[pdf]|[web]

[73] Jeffrey S. Rosenthal, "Independent Statistical Analysis of Nova Scotia Lottery Data." July 2007. [web]

[74] Nova Scotia Provincial Lotteries \& Casino Corporation. "Integrity and Security Update," October 2, 2007 (webpage). [pdf] [web]

[75] Amy Smith. "Lottery harder to win in Atlantic Canada; Chance of winning lottery even less in Atlantic region, statistician says." Sunday Herald, May 13, 2007, p. A6. [text] 
[76] Colby Cosh. "The joyless luck club." National Post, March 16, 2007. [text]|[pdf]|[web]

[77] David Jackson. "Lottery Corp. may alter security check policy." Chronicle Herald, November 8, 2007, p. B2. [text]

[78] Nova Scotia. Ministerial Advisory Panel on Ticket Lottery Controls. "Report on Controls and Regulation of Atlantic Lottery Corporation Ticket Lotteries in Nova Scotia: To the Minister of Environment and Labour." 2007.

[79] David Jackson. "Shhh! We have a winner; Lotto Corp. didn't say pot went to retailer." Chronicle-Herald, January 10, 2008, p. A1.[text]

[80] Canadian Press. "Atlantic Lottery withholds bonuses for execs after review of retailers' wins." January 10, 2008. [text]

[81] Ernst \& Young. "Western Canada Lottery Corporation: Review of Consumer/Retailer Prize Claim Processes for the." October 2007. [web]

[82] Jeffrey S. Rosenthal, "Analysis of Western Canada Retailer Lottery Wins." January 2009. [web]

[83] Canadian Broadcasting Corporation. "Western lottery clerks claiming high number of prizes: CBC investigation." CBC News, February 9, 2009 (webpage). [pdf]|[web]

[84] Canadian Broadcasting Corporation. "Review launched into insider wins at Western lottery." CBC News, February 9, 2009 (webpage). [text] [pdf] [web]

[85] Canadian Broadcasting Corporation. "Manitoba ombudsman reopening case on lottery wins." CBC News, February 27, 2009. [text] [pdf] [web]

[86] Bruce Owen. "Province reassures nervous lottery ticket buyers." Winnipeg Free Press, February 10, 2009, p. A5. [text]][pdf] [web]

[87] Jeffrey S. Rosenthal, "An explanation of the discrepancy between the expected retailer win rate reported by the $\mathrm{CBC}$, and that reported by Ernst \& Young." $C B C$ News, February 12, 2009. [pdf] [web]

[88] Mary Lamey. "No fraud here, agency says: 'Insiders' exposed; Too many retailers win in Ontario: CBC." Montreal Gazette, October 26, 2006, p. A1. [[text]]

[89] Société Radio-Canada. "Les voleurs de loto" (episode of Enjeux), broadcast on SRC Télévision, March 14, 2007 (webpage). [pdf] [[web]

[90] Société Radio-Canada. "Les voleurs de loto" (episode of Enjeux), broadcast on SRC Télévision, March 14, 2007. Transcript. [pdf]

[91] Société Radio-Canada. Episode of Enqute, broadcast on SRC Télévision, November 1, 2007. Transcript. [pdf]

[92] Katia Gagnon. "Loto-Québec s'attaque à la fraude." La Presse, May 1, 2008, p. A13. [text]

[93] Lourdes Medrano. "Prosecutor: Store clerk stole \$1M Pick ticket." Arizona Daily Star, January 13, 2006, p. B1. [text]

[94] Daily Mail. "Not so lucky: $\$ 1 \mathrm{~m}$ lottery winner left empty-handed after shop worker pockets his prize." Daily Mail (U.K.), October 23, 2009. [text] [[pdf] [web]

[95] Texas Lottery news story. [web] 
[96] Dan McCue. "\$1 million winner says Texas Lottery owes him." Courthouse News Service, June 2, 2011. [text] [pdf] [web]

[97] Dave Moore. "Texas lottery officials find themselves in deposition hot seat." Androvett Blog, Androvett Legal Media and Marketing, August 12, 2011. [[pdf]|[web]

[98] Associated Press Newswires. "Texas Lottery refers 6 cases to prosecutors." December 22, 2009. [text]

[99] Rod Boshart. "Ombudsman: Lottery system lax in ferreting out fraud." The Gazette, (Cedar Rapids, Iowa), April 21, 2009. [text]

[100] William P. Angrick II. Taking Chances on Integrity: An Investigation of the Iowa Lottery. April 21, 2009. [pdf] [web]

[101] NBC. "How lucky can you get?" Dateline, broadcast on NBC Television, May 3, 2009. Transcript. [text]][web]

[102] California Lottery. "Press release: Lottery consumer protection operation in San Diego County stings retailer rip-offs." California Lottery, June 12, 2008 (webpage).[pdf]][web]

[103] California Lottery. "Press release: Lottery consumer protection operation stings retailer rip-offs." California Lottery, June 26, 2008 (webpage). [pdf]|[web]

[104] California Lottery. "Press release: Lottery consumer protection operation stings retailer rip-offs." California Lottery, July 1, 2008 (webpage). [pdf]|[web]

[105] California Lottery. "Press release: Lottery stings retailer rip-off in Riverside County." California Lottery, December 17, 2008 (webpage). [pdf] [[web]

[106] California Lottery. "Press release: Lottery stings retailer rip-off in Fresno County." California Lottery, January 21, 2009 (webpage). [pdf] [web]

[107] California Lottery. "Press release: Lottery stings retailer rip-off in Northern California." California Lottery, February 18, 2009 (webpage). [pdf] [web]

[108] California Lottery. "Press release: Lottery stings retailer rip-off in Santa Clara County." California Lottery, March 4, 2009 (webpage). [[pdf]|[web]

[109] California Lottery. "Press release: Lottery stings retailer rip-off in Riverside County." California Lottery, June 25, 2009 (webpage). [[pdf]|[web]

[110] California Lottery. "Press release: Lottery stings retailer rip-off in Stockton." California Lottery, September 9, 2010 (webpage). [pdf] [[web]

[111] Lora Pabst. "Lottery sting might have caught clerks trying to cash in" Star-Tribune, March 28, 2009, p. 1B. [text]

[112] Ohio Lottery. "Press release: Lottery security program results in arrest of store clerk." Ohio Lottery, May 05, 2010 (webpage). [text] [pdf]|[web]

[113] Ohio Lottery. "Press release: Ravenna store owner arrested after lottery fraud." Ohio Lottery, June 30, 2010 (webpage). [text] [pdf] [web]

[114] Canadian Broadcasting Corporation. "Police open probe of fraudulent Ontario lottery wins." CBC News, March 27, 2007 (webpage). [text] [pdf]|[web]

[115] Sam Pazzano. "Jail lotto bandit, Crown says." Toronto Sun, April 15, 2010.[text][[pdf] [web] 
[116] Canadian Broadcasting Corporation. "Man jailed for stealing $\$ 5.7 \mathrm{M}$ lottery win." $C B C$ News, June 15, 2010 (webpage). [text] [pdf] [web]

[117] Sam Pazzano. "Store owner admits lottery fraud: Store owner tells court he took ticket worth \$5.75M from rightful owners in June 2004." Toronto Sun, December 5, 2009. $[$ text $][$ pdf $][$ web]

[118] National Post. "True lottery winners get \$5.7M from OLG." Windsor Star, December 20, 2007. [text] [pdf] [web]

[119] Dale Anne Freed. "Lotto winner paid four years later." Toronto Star, December 17, 2008. [text] [ [pdf] [web]

[120] Ontario Lottery and Gaming Corporation. "Burlington woman collects $\$ 80 \mathrm{~K}$ prize on ticket she purchased in 2004." Press release. December 16, 2008 (webpage). [pdf]|[web]

[121] Canadian Press "Ontario store manager charged with theft of $\$ 80,000$ lottery ticket." October 31, 2008. [text]

[122] Canadian Broadcasting Corporation. "Luck of the Draw" (episode of The Fifth Estate), broadcast on CBC Television, March 14, 2007. [web]

[123] Canadian Broadcasting Corporation. " $\$ 12.5 \mathrm{M}$ lottery prize theft leads to 3 arrests." CBC News, September 29, 2010 (webpage). [pdf] [web]

[124] Curtis Rush and Jayme Poisson. " $\$ 12.5 \mathrm{M}$ lottery ticket stolen; police seeking rightful winner." Toronto Star, September 30, 2010. [pdf] [[web]

[125] 680News. "OLG team up with cops to find rightful owner of \$12.5-million ticket." 680News, September 29, 2010 (webpage). [[pdf]|[web]

[126] Tamara Cherry. "Flurry of calls for allegedly stolen jackpot." Toronto Sun, September 30, 2010. [text] [ [pdf] [ [web]

[127] Canadian Press. "OLG forwards hundreds of claims for allegedly stolen jackpot to police." Toronto Star, October 10, 2010. [text] [pdf]|[web]

[128] Lesley Ciarula Taylor. "Lottery fraud victims claim $\$ 12.5 \mathrm{M}$ prize - plus interest." Toronto Star, January 27, 2011. [text] [pdf] [web]

[129] Canadian Broadcasting Corporation. "Lottery scam victims finally get $\$ 12.5 \mathrm{M}$." $C B C$ News, January 27, 2011 (webpage). [text] [pdf] [web]

[130] Canadian Press. "Victims of alleged insider lottery scam get \$12.5-million jackpot." Globe and Mail, January 27, 2011. [pdf][[web]

[131] CTV. "Rightful winners of 2003 lottery finally claim jackpot" CTV News, January 27, 2011 (webpage). [ [text] |[pdf]|[web]

[132] Thane Burnett. "Solving equations and solving crime: Toronto math prof proves his point when it comes to insiders winning lottery prizes." Toronto Sun, February 21, 2009. [text] $[$ [pdf] $][$ web] 